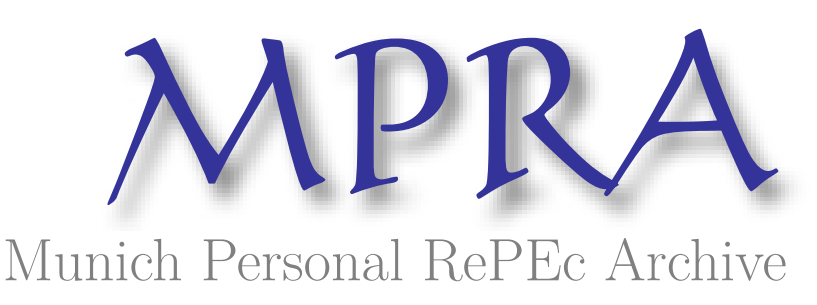

\title{
The Asian Model: A Crisis Foretold?
}

Singh, Ajit

1998

Online at https://mpra.ub.uni-muenchen.de/24683/

MPRA Paper No. 24683, posted 02 Sep 2010 12:48 UTC 


\title{
The Asian Model: A Crisis Foretold?
}

\author{
Ajit Singh and Bruce A. Weisse \\ University of Cambridge, UK
}

\section{$\underline{\text { I. Introduction }}$}

The East Asian countries achieved extraordinarily fast economic growth during the last four decades. Indeed, it would be no exaggeration to say that they represented the most successful case of rapid industrialisation and sustained economic growth in the history of mankind. An economy like South Korea's was unequivocally industrially backward in the mid-1950s. Its per capita industrial output was at the time US\$ 8 compared with US\$ 7 for India and US\$ 60 for Mexico. By mid 1990, the country was the fifth largest car producer in the world, the largest producer of DRAM microchips, and the home of the world's most efficient steel industry. Its per capita income had increased from $x$ dollars to nearly US\$10,000 over a thirty-five year time span.

The Korean story of fast industrialisation and technological catch up is by no means unique. The other three countries in the Gang of Four - Taiwan, Hong Kong and Singapore also achieved similar economic success. More recently, these four countries were followed by Malaysia, Thailand and Indonesia who also recorded sustained and rapid growth of per capita income. Significantly, these "miracle" countries not only expanded at a fast rate but they also did so without any worsening of income distribution. Their record of poverty reduction has been truly remarkable. As Professor Joseph Stiglitz, the World Bank's Chief Economist, notes: "In 1975, six out of 10 Asians lived on less than $\$ 1$ a day. In Indonesia, the absolute poverty rate was even higher. Today, two out of 10 East Asians are living in absolute poverty. Korea, Thailand and Malaysia have eliminated poverty and Indonesia is within striking distance of that goal. The USA and other western countries, which have also 
seen solid growth over the last 20 years but with little reduction in poverty rates, could well learn from the East Asian experience (Stiglitz, 1998)."

These "miracle" economies, with an acknowledged record of economic success, have suddenly and simultaneously suffered an extraordinary reversal which justifies the term economic meltdown. Until the eve of the crisis (which can be dated July 2, 1997 when the Thai authorities floated the baht), the economic management of Indonesia (the worst hit economy) was being praised by the IMF and the World Bank. It would also be true to say that no one had predicted this extraordinary turn of events for what had emerged as the most dynamic region of the world economy. ${ }^{1}$ Between 1980 and 1995, the developing East Asian economies were growing at a rate nearly three times that of the world economy.

As the crisis has developed a number of theories have been put forward to explain it. One of the most influential analyses ascribes the crisis to the underlying model of guided capitalism which most of these countries had been following in one form or another. The widely respected Chairman of the US Federal Reserve, Mr. Alan Greenspan, advanced this thesis in the following terms:

[In the last decade or so, the world has observed] a consensus towards, for want of a better term, the Western form of free-market capitalism as the model which should govern how each individual country should run its economy...We saw the breakdown of the Berlin wall in 1989 and the massive shift away from central planning towards free market capitalist types of structures. Concurrent to that was the really quite dramatic, very strong growth in what appeared to be a competing capitalist-type system in Asia. And as a consequence of that, you had developments of types of structures which I believe at the end of the day were faulty, but you could not demonstrate that so long as growth was going at 10 percent a year. ${ }^{2}$

1 It could be argued that there were some worries about Thailand's property market bubble and the weakness of its financial system before the crisis. This, however, was not so in relation to other countries. Even in the case of Thailand the government was carrying out reforms to improve the bank system.

${ }^{2}$ Quoted in the International Herald Tribune, 13 February 1998. 
The same thesis is more graphically put by Richard Hornik in the popular Time magazine as follows:

...For it is the top-down nature of the Asian model itself that is the real cause of the crisis. This model bred complacency, cronyism and corruption. Isolated from public opinion, just as they insulated bankers and businessmen from market forces, the technocrats ignored the deafening clamour of alarm bells that market forces have been ringing for years...The financial crisis facing Asia today is merely a symptom of a much deeper problem. The social and political assumptions on which the Asian model was founded are terribly outdated. The global economy is far too complex and fast paced for any bureaucrats to control. The only miracle in Asia is that this approach worked as long as it did.

More significantly, these views are central to the IMF's analysis of the crisis and their policy programme. As conditionality for its multi-billion dollar bailout packages which the fund has arranged, these countries are being asked to bring about fundamental reforms in their economic systems. They are asked to change, among many other things, their systems of corporate governance, labour laws, and competition laws so as to rid these economies of "crony capitalism" and "nontransparency" and myriad market rigidities such as life-time employment in South Korea.

The present paper critically examines this thesis. It will first outline the main characteristics of the Asian model of capitalism. It will be argued here that this thesis is not only incorrect, but that the policy recommendations based on it are likely to prolong the crisis rather than to alleviate it whilst also undermining the prospects for long-term growth. The paper, therefore, recommends a fundamental change in the IMF's analytical and policy approach to the crisis.

\section{The Asian Model}


What are the main characteristics of the East Asian model? What is the causal connection between them and the crisis?

The Asian model is perhaps best epitomised by the experience of Japan during its high growth phase from 1950 to 1973 . During that period the Japanese economy achieved unprecedented structural transformation and economic growth. Between 1953 and 1973, manufacturing production expanded at a rate of $13 \%$ per annum while GDP expanded by nearly $10 \%$ per annum. Although it started from a low level, Japan's share of world exports of manufactures increased by a huge ten percentage points during this period.

Economic organisation of the country during this high growth phase involved heavy state intervention in all spheres of the economy (the intervention was much reduced and the Japanese economy became much more open following its accession to OECD membership around 1970). There was a close relationship between government and business and between them and the financial system. Furthermore, the relationship between the financial system and the corporation was of a rather different kind than that found in the US and the UK.

Professors Caves of Harvard University and Professor Uekusa of Tokyo University in their classic study Industrial Organisation in Japan correctly portrayed the relationship between government and business in Japan as follows:

Each sector of the Japanese economy has a cliental relation to a ministry or agency of the government. The ministry, in addition to its various statutory means of dealing with the economic sector, holds a general implied administrative responsibility and authority that goes well beyond what is customary in the United States and other Western countries. While the Ministry of International Trade and Industry (MITI) plays the most prominent role, its operations are not distinctive. "The industrial bureaus of MITI proliferate sectoral targets and plans; they confer, they tinker, they exhort. This is the economics by admonition to a degree 
inconceivable in Washington or London. Business makes few major decisions without consulting the appropriate governmental authority; the same is true in reverse." (Caves and Uekusa, 1976, p.149)

More specifically, following Singh (1997, 1998b, 1998c), Amsden and Singh (1994), Amsden (1989), and Evans (1987), some of the more important characteristics of the Japanese model - which were subsequently emulated to a greater or lesser degree by other Asian countries - can be summarised as follows:

1. Although there was a close relationship between government and business and extensive consultation through the so-called "deliberation councils", an important characteristic which distinguished East Asian from other dirigiste states was that the government provided assistance to the corporations only in return for adherence to strict performance standards.

2. Interventions were carried out through a system of administrative guidance rather than through formal legislation. In order for this system not to be subject to private rent-seeking or social abuse, it required a certain autonomy for the permanent civil service which guided the economy. Such relative autonomy prevailed in East Asian states to a far greater degree than in Brazil, Mexico or India.

3. The relationship between the corporation and the financial system in countries like Japan and Korea has also been very different from that of the US and the UK. The former countries have followed, for example, the socalled main bank system which involves long-term relationships between the corporations and the main banks. This enables Japanese or Korean managers to take a long-term view in their investment decisions. The managers are not constrained by the threat of hostile take-overs on stock markets as is the case in the Anglo-Saxon countries. (Aoki and Patrick, 1992; Odagiri, 1994)

4. There are differences in the internal organisation of East Asian corporations compared with those of the US and the UK. The former involve a co- 
operative relationship between management and labour, epitomised by the system of lifetime employment in the successful large corporations. This implies considerable imperfections in the labour market. (Dore, 1986; Aoki, 1990)

5. As for the competition in product markets, such competition is not regarded by the East Asian authorities as an unalloyed good. Unlike in countries like the US, economic philosophy in the East Asian countries does not accept the dictum that "the more competition the better." The governments in these countries have taken the view that, from the perspective of promoting investment and technical change, the optimal degree of competition is not perfect or maximum competition. The governments have therefore purposefully managed and guided competition: it has been encouraged but also restricted in a number of ways. (Amsden and Singh, 1994)

6. Following this basic economic philosophy outlined above, the East Asian governments have sought not "close" but what might be called "strategic" integration with the world economy, i.e. they have integrated up to the point where it has been useful for them to do so. Thus, during their high-growth, developmental phases, Japan (between 1950-1973) and Korea (1970s and 1980s) integrated with the world economy in relation to exports but not imports; with respect to science and technology but not finance and multinational investment. (Chakravarty and Singh, 1988)

It will be appreciated that the characteristics of the Asian model outlined above are of an ideal type. At one level, each country has specificities which are important. More generally, the South East Asian economies such as Malaysia and Indonesia were much more open in terms of FDI and other capital inflows than South Korea. The degree and effectiveness of state intervention also varied between countries with Korea being at the top end and perhaps Thailand at the bottom end. Nevertheless, there is a pronounced family resemblance in the way these countries do business and structure their institutions that sets them apart from the US and the UK as well as other developing regions. 


\section{The Crisis and the Asian Model}

Table 1 indicates the contours of the financial crisis. It shows the collapse of the stock markets and the currency markets in the crisis-affected countries. From July 1, 1997 to February 18, 1998, the stock market in the worst hit country, Indonesia, fell by over $80 \%$ and the exchange rate against the US\$ by almost $75 \%$. The currency and stock markets had evidently interacted with each other in a negative feedback loop in response to external shocks.

Those who attribute the crisis fundamentally to the underlying model of capitalism in the Asian economies have a difficulty in linking the two phenomena. For the important question is, if the model was deficient, why was it so extraordinarily successful for so long? What caused the sudden collapse? To be satisfactory, a theory of the crisis must be able to account for both of these aspects.

Krugman had argued in an influential paper (1994) that the success of the these economies was unlikely to be sustainable over a long period. Using the growth accounting framework, he cited evidence from Alwyn Young and others to indicate that the Asian economic miracle was based on greater use of inputs rather than a more productive use of them. Since there were obvious limits to the growth of inputs of labour and capital, he thought that these economies would inevitably slow down. This analysis, however, was by no means universally accepted. Critics took issue with both the evidence and its interpretation. They also pointed to the limitations of the growth accounting framework which made their conclusions highly dependent on a very narrow methodology. In any case, even if Krugman's thesis was correct, this cannot explain the suddenness of the Asian collapse. The slowdown in growth predicted by the analysis would have occurred gradually and asymptotically, rather than immediately and all at once.

It is also ironic, as Stiglitz points out, that the international financial institutions who are now ascribing the crisis to excessive government intervention were not too long 
ago denying that there was much government intervention at all in these economies. When it was successful the model was being interpreted as one of a minimalist state in which the government only provided the overall framework for private enterprise to flourish. Now that these countries have suffered a crisis, it is being conveniently argued that it is due to extensive state intervention (World Bank 1991; for a critique see Singh 1994, 1998c).

More serious attempts to relate the Asian model to the crisis such as that of the IMF (1998) involves the notion of over-investment, disregard of profits, and the lack of competition in these economies. It is suggested that close government-business relations led to "crony capitalism" which in turn led to excessive investment in unprofitable or marginal projects. This analysis may explain a weakness of the system which could lead to a slowdown in economic growth, but why should it happen so suddenly? Here the critics of the Asian model put forward two important arguments. First, the fact that the combination of government-business-finance interrelationships generated a highly geared corporate sector. High gearing made the corporate sector financially fragile and vulnerable to interest rate shocks. Krugman suggests that "crony capitalism" contributed to financial fragility through its pervasiveness in the critical financial sector. The financial sector was underregulated, political favouritism permitted it to over-invest in areas such as property, and was also subject to implicit guarantees that the government would bail it out if serious problems developed (Krugman, 1998).

The other argument is made in terms of transparency. The markets did not have adequate information about the true financial status of the corporations and the banks. Once the markets began to assess the true facts, there was a collapse of confidence. As the Managing Director of the IMF, Mr. Camdessus, put it:

In Korea, for example, opacity had become systemic. The lack of transparency about government, corporate and financial sector operations concealed the extent of Korea's problems - so much so that corrective action came too late and ultimately could not prevent the collapse of 
market confidence, with the IMF finally being authorised to intervene just days before potential bankruptcy. ${ }^{3}$

To sum up, the critics of the Asian model can plausibly explain both the slowdown and its suddenness by invoking the lack of transparency, financial fragility, and an inadequately regulated and unsound financial system dominated by political cronyism.

\section{The Financial Crisis: Preliminary Analytical and Empirical Considerations}

The above analysis linking the financial crisis to the Asian model may be plausible, but is it analytically and empirically correct?

The first important issue is that of the fundamentals. Tables 2 and 3 present information on the relevant variables for the Asian countries directly affected by the crisis as well as for three countries not directly affected by the crisis - India, Mexico and Brazil. Compared with the latter three countries the Asian economies all had by and large strong fundamentals as indicated by the following variables:

$$
\begin{aligned}
& \text { - } \\
& \text { - } \\
& \text { - } \\
& \text { - } \\
& \text { low, single digit rates of inflation } \\
& \text { - } \\
& \text { fiscal soundness with low public debt to GDP ratios } \\
& \text { export orientation and high rates of growth of exports }
\end{aligned}
$$

However, as Table 2 indicates, the current account deficits of the Asian countries tended to be somewhat larger than those of India, Mexico and Brazil. This partly reflected the fact that countries like Malaysia were major recipients of FDI. However, in each case the deficits were sustainable and had not constrained fast economic growth in previous years. Furthermore, prior to the crisis the current

\footnotetext{
${ }^{3}$ Speech to Transparency International, reported in the IMF Survey, 9 February 1998.
} 
accounts of the Asian countries had generally been improving. For example, the Malaysian deficit had come down from 10\% of GDP in 1995 to 5-6\% in 1996-1997.

To sum up, as Singh (1998d) notes all the affected Asian countries had strong "fundamentals" in the sense of a proven record of being able to sustain fast economic growth. In view of their export orientation, they also had the ability to service their debts in the medium- to long-term. They did, however, suffer to varying degrees from short term imbalances such as overvalued exchange rates, as well as short term liabilities of the financial sector which exceeded the value of central bank reserves. This required some macroeconomic adjustments and restructuring of debts. In other words, these countries had problems of liquidity rather than solvency. Finally, Wolf's (1998) observations on the country most affected by the crisis, Indonesia, are most apt:

Dwell for a moment, on Indonesia: its current account deficit was less than 4 percent of GDP throughout the 1990's; its budget was in balance; inflation was below 10 percent; at the end of 1996 the real exchange rate (as estimated by J.P. Morgan) was just 4 percent higher than at the end of 1994; and the ratio to GDP of domestic bank credit to the private sector had risen merely from 50 percent in 1990 to 55 percent in 1996. True, the banking system had mountains of bad debt, but foreign lending to Indonesian companies had largely bypassed it. Is anyone prepared to assert that this is a country whose exchange rate one might expect to depreciate by about 75 percent? Some exchangerate adjustment was certainly necessary; what happened beggars belief. (Wolf, 1998)

The external capital flows to the affected countries summarised in Table 4 indicate the proximate cause of the financial crisis was a sudden reversal of external capital flows. From 1994 to 1996 net private capital inflows to the Asian countries more than doubled (rising from $\$ 40.5$ billion to $\$ 90.3$ billion). However, in 1997 there was a net outflow of $\$ 12$ billion, a turnaround of over $\$ 100$ billion, which is equivalent to about $10 \%$ of the GDP of these countries. Although portfolio flows were fickle (a 
positive figure of $\$ 12$ billion in 1996 turned to a negative figure of $\$ 11.6$ billion in 1997), the main offenders were the commercial banks: their lending to the affected countries had risen from \$24 billion in 1994 to \$55 billion in 1996. But in 1997 there was a net withdrawal of funds by the banks to the tune of $\$ 21.3$ billion.

The overall evidence supports the argument of Radelet and Sachs (1998) that this was a classic case of a panic run on the bank where each bank considered only the shortterm illiquidity of the countries concerned and consequently withdrew its funds, exacerbating the loss of confidence and making the crisis worse for both borrowers and lenders. In more technical terms, the two authors suggest that in the financial markets there may be multiple equilibria and in the absence of co-ordination, the economic agents in this particular case ended up in a highly suboptimal equilibrium. Feldstein (1998) similarly notes that the IMF insistence that the crisis was caused by fundamental flaws intrinsic to these economies may have contributed to this bad equilibrium by frightening already skittish investors. Instead of opting for multibillion dollar bailouts with far reaching conditionality, both these analyses suggest that the most useful policy for the IMF to pursue would have been to emphasise the sound fundamentals of these countries, their phenomenal success in export markets, their strong supply-side capabilities and their ability to service in the medium- to long- term their debt obligations. In other words, the IMF should have acted as a coordinator between borrowers and lenders to help match the maturity structure of the debt to the countries' ability to repay it and thus help generate a far more optimal equilibrium.

\section{Was the Asian model responsible for the crisis?}

We turn now to the specific issues raised with respect to the aspects of the Asian model which may have contributed to the crisis, starting with the suggestion that the reason for the market's overreaction was the lack of transparency in the corporate and financial systems of the Asian countries. This issue requires serious analysis and several points need to be considered. 
First, the banks in Germany have also traditionally been less than transparent in the accounts they maintain with hidden reserves and often hidden provisions for losses. Indeed, many practitioners would regard transparency in banking as not being particularly virtuous. As the new President of the European Central Bank, Wim Duisenberg, observed in the first speech after his appointment, what is required is accountability rather than transparency.

Secondly, it will be appreciated that banking crises are endemic to capitalism and can occur with or without transparency. For example, as recently as the early 1990s the Scandinavian countries, which would be very high in any international transparency league, had a full-blown banking crisis with serious affects on the real economy.

Thirdly, on the subject of the availability of financial information, Professor Lamfalussy, the former chief economist of the Bank of International Settlements, has noted in a letter to the Financial Times:

...the Bank for International Settlement is encouraged to speed up the publication of its statistics on international bank lending...The suggested improvement will surely do no harm but it will not do much good either as long as market participants and other concerned parties fail to read publicly available information or to draw practical conclusions from it.

In the summer of 1996 the BIS reported in its half yearly statistics that by end-1995 the total of consolidated bank claims on South Korea, Thailand, Indonesia, and Malaysia reached \$201.6bn....It was therefore known by mid-summer 1996 that bank claims maturing within one year made up 70 per cent of the total for South Korea, 69.4 per cent for Thailand, 61.9 per cent for Indonesia, but "only" 47.2 per cent for Malaysia. 
The BIS (1998) report therefore rightly notes that information and transparency will not be enough to eliminate financial crises, rather "what is also needed is the vision to imagine crises and the will to act pre-emptively."

Finally, it is not without interest in this connection to note that international banks had lent in the case of Korea huge sums of money to newly established merchant banks all of which did not have a long enough track record and many of which were poorly managed (Chang, 1998). In normal circumstances, whether or not there is transparency, such lending would be regarded as imprudent or even reckless; unless, of course, the banks had reason to believe that they would be repaid their monies either by the government or through a International Monetary Fund bailout.

Turning to the question of over-investment and the misallocation of resources, it is strange that this is being ascribed to the failings of the Asian model. For in the normal workings of the Asian model, the government would have controlled the allocation of investment to unfavoured sectors such as real estate. It would also have co-ordinated investment activity so as to maintain profits (Singh, 1998b). It was precisely by abandoning the main tenets of the Asian model through financial liberalisation that the present imbalances were allowed to occur.

Financial liberalisation was also a major factor in making the traditional corporate sector in Asian countries fragile. As Table 5 shows, South Korea's corporate sector was the most highly geared of the nine emerging markets in the sample (as measured by debt/equity ratios). After South Korea, the Indian corporate sector is the second most highly geared - with a higher debt/equity ratio than either Malaysia or Thailand. India, however, did not have a financial crisis (for reasons which are discussed later).

Before financial liberalisation in Korea, the high debt/equity ratios were not a significant problem. Such high debt/equity ratios arose from the fact that the Korean chaebol expanded at a very fast rate with the help of loans provided by statecontrolled banks. This enabled families with a small equity base to both own and control very large corporations. These chaebol were themselves the creation of the government and were used as a vehicle for the government's drive for rapid 
industrialisation and technological catch-up. In view of the nature of the risks involved in vast investments in new products and processes in a developing country, left to themselves the private corporations would not have been willing to undertake such risky activities. But with government encouragement and its willingness to share the risks involved with the enterprise, and in view of the fierce competition with the other chaebol, they were willing to undertake such risks. Technological risks were thus socialised and the resulting system produced a very fast industrialisation of the country that enabled Korea to capture world markets in an ever increasing range of more and more sophisticated products.

As Lee (1992) has argued, what the government in effect was doing was operating an internal capital market. Such a market, as Williamson (1975) pointed out in his seminal analysis of the internal allocation of capital by conglomerates, may in many circumstances be more efficient than an external capital market. The latter is often subject to speculation, asymmetric information and myriad other market inefficiencies. Stock market prices which emerge may not be efficient in Tobin's fundamental valuation sense (i.e. they may be subject to speculative influences, whims and fashions).

However, financial liberalisation fundamentally changed this whole system. High debt/equity ratios without the government's active involvement in risk taking made the corporate system fragile. Furthermore, it was accentuated by the fact that not only was the overt government control over corporate borrowings (particularly abroad) and investment abandoned, but it was not even replaced by adequate prudential regulation.

That precipitate financial liberalisation rather than the Asian model has been the main factor in the financial crisis of the affected countries is also indicated by the experience of India and China. The Indian fundamentals, as Table 3 suggests, are considerably worse than those in the Asian countries struck by the crisis. Yet India was able to maintain relative currency stability as well as avoid stock market panics despite the fact that the country in the recent period has been subject to considerable policy uncertainty because of unstable governments. The main reason is that 
although it has introduced some capital account liberalisation, it maintains extensive and comprehensive controls, particularly over borrowings abroad by individuals, corporations or banks (Singh 1998a).

Similarly, China has been able to avoid financial crisis by maintaining extensive controls on capital movements. This is particularly notable in view of the fact that in the most recent period, China has suffered reduced economic growth and considerable slowing down of the rate of growth of its exports. It is also interesting that despite capital controls, the country, during the last decade, has been the largest recipient of FDI inflows in the developing world.

\section{Conclusion and Policy Implications.}

This paper has argued that the influential thesis of the US government and the IMF that the fundamental causes of the Asian financial crisis lie in the dirigiste model of guided capitalism followed by these countries is seriously mistaken. The crisis has arisen in large measure by precipitate financial liberalisation which involved the abandonment of the essential tenets of the model.

Unfortunately in the case of the IMF, the mistaken diagnosis has inevitably lead to wrong policy prescriptions which have exacerbated rather than alleviated the crisis. Apart from ascribing the crisis "fundamentally" to the Asian model, at the beginning of the crisis the Fund also evidently interpreted it as a traditional balance of payments crisis brought about by government fiscal excesses. Its policy prescriptions therefore involved the usual remedies of fiscal and monetary contraction and high interest rates. To cope with the fundamental structural causes of the crisis (i.e. the dirigiste model), the Fund recommended further financial liberalisation together with far reaching changes in basic social institutions.

The consequences of this misdiagnosis and of the policies which followed from it have been catastrophic. The Fund had originally estimated that as a result of its bailouts and conditionalities, GDP in affected countries would contract, but only by 
relatively small amounts. It failed fully to appreciate that the Asian crisis was not of the traditional type, but that it was a crisis caused by private rather than public profligacy, and that it was a crisis of the capital account rather than the current account. ${ }^{4}$ In these circumstances, the Fund's policy of high interest rates and fiscal austerity have managed to effectively bankrupt the corporate and banking sectors and thereby generate a deep depression in the stricken economies. Far from the small contraction the IMF foresaw, Goldman Sachs now forecasts that in 1998 real GDP will contract by $15 \%$ in Indonesia, $8 \%$ in Thailand, and $7 \%$ in Korea.

To restore economic health to Asian economies would require a radical change in the IMF's analyses and policy prescriptions. At the level of political economy, one important policy implication of this paper is that the deep crisis makes it all the more necessary for the affected countries to not only maintain the close governmentbusiness relationships of the Asian model, but indeed to extend them to involve trade unions and groups in civil society. The resolution of the crisis requires credible policies which must necessarily be based on co-operation and equitable sharing of the burden of adjustment.

\footnotetext{
${ }^{4}$ Some may argue that even if the IMF had analysed the problem correctly they would have still applied the traditional medicine, but in that case they would at least have had to present a different justification. This could have taken the form that the austerity policies are demanded by the market in order to restore confidence.
} 


\section{$\underline{\text { References }}$}

Amsden, A. 1989. Asia’s Next Giant. New York: Oxford University Press.

Amsden, A. and Singh, A. 1994. "The optimal degree of competition and dynamic efficiency in Japan and Korea.” European Economic Review 38:941-951.

Aoki, M. 1990. "Toward an economic model of the Japanese firm.” Journal of Economic Literature 28:1-27.

Aoki, M. and Patrick, H. (eds.) 1992. The Japanese Main Bank System: Its Relevance for Developing and Transforming Economies. Oxford: Clarendon Press.

Bank for International Settlements. 1998. Annual Report. Basle: BIS.

Caves, R. and Uekusa, M. 1976. Industrial Organisation in Japan. Washington: The Brookings Institution.

Chakravarty, S. and Singh, A. "The desirable forms of economic openness in the South.” Helsinki: World Institute for Development Economics Research.

Chang, H-J. 1998. "Reform for the long-term in South Korea", International Herald Tribune, 13 February 1998.

Dore, R. 1986. Flexible Rigidities: Industrial Policy and Structural Adjustment in the Japanese Economy, 1970-1980. London: The Athlone Press.

Evans, P. 1987. "Class State, and Dependence in East Asia: Lessons for Latin Americanists", in F.Deyo (ed.), The Political Economy of the New Asian Industrialism. Ithaca: Cornell University Press.

Feldstein, M. 1998. "Refocusing the IMF.” Foreign Affairs, March/April. 
International Monetary Fund. 1998. World Economic Outlook. Washington: IMF.

Krugman, P. 1994. "The myth of Asia's miracle.” Foreign Affairs, Vol.73, No.6.

Krugman, P. 1998. "What happened to Asia?" Unpublished.

Lee, C.H. 1992. "The government, financial system and large private enterprises in economic development in South Korea." World Development 20:187-197.

Odagiri, H. 1994. Growth Through Competition, Competition Through Growth: Strategic Management and the Economy in Japan. Oxford: Clarendon Press.

Radelet, S. and Sachs, J. 1998. “The East Asian Financial Crisis: Diagnosis, Remedies, Prospects.” Cambridge, Mass.: Harvard Institute for International Development.

Singh, A. 1998a. "Liberalisation, the stock market and the market for corporate control: A bridge too far for the Indian economy?"

Singh, A. 1998b. "Savings, investment and the corporation in East Asia," Journal of Development Studies

Singh, A. 1998c. "Competitive markets and economic development: A commentary on World Bank analyses," in P. Arestis and M. Sawyer (eds.), The Political Economy of Economic Policies. London: Macmillan.

Singh, A. 1998d. "Asian capitalism and the financial crisis." Paper presented at the Conference on World Economic Governance, Robinson College, Cambridge, May. Forthcoming in a volume of essays edited by J. Grieve Smith and J. Michie.

Singh, A. 1997. "Catching up with the West: A perspective on Asian economic development and lessons for Latin America," in L. Emmerij (ed.), Economic and 
Social Development into the XXI Century. Washington: Inter-American Development Bank.

Singh, A. 1994. "Openness and the market-friendly approach to development: Learning the right lessons from development experience." World Development 22:1811-1823.

Stiglitz, J. 1998. "Restoring the Asian Miracle", Wall Street Journal, Europe, 3 February, p.4).

Williamson, O. 1975. Markets and Hierarchies: Analysis and Antitrust Implications. New York: The Free Press.

Wolf, M. 1998. "Flows and blows.” Financial Times, 3 March 1998.

World Bank. 1991. World Development Report. Washington: World Bank. 